\title{
Front Matter: Volume 6684
}

, "Front Matter: Volume 6684," Proc. SPIE 6684, Atmospheric and Environmental Remote Sensing Data Processing and Utilization III: Readiness for GEOSS, 668401 (26 October 2007); doi: 10.1117/12.759503

SPIE Event: Optical Engineering + Applications, 2007, San Diego, California, United SPIE. States 


\section{PROCEEDINGS OF SPIE}

\section{Atmospheric and Environmental Remote Sensing Data Processing and Utilization III: Readiness for GEOSS}

Mitchell D. Goldberg

Hal J. Bloom

Allen H. Huang

Philip E. Ardanuy

Editors

27-28 and 30 August 2007

San Diego, California, USA

Sponsored and Published by

SPIE

Volume 6684 
The papers included in this volume were part of the technical conference cited on the cover and title page. Papers were selected and subject to review by the editors and conference program committee. Some conference presentations may not be available for publication. The papers published in these proceedings reflect the work and thoughts of the authors and are published herein as submitted. The publisher is not responsible for the validity of the information or for any outcomes resulting from reliance thereon.

Please use the following format to cite material from this book:

Author(s), "Title of Paper," in Atmospheric and Environmental Remote Sensing Data Processing and Utilization III: Readiness for GEOSS, edited by Mitchell D. Goldberg, Hal J. Bloom, Allen H. Huang, Philip E. Ardanuy, Proceedings of SPIE Vol. 6684 (SPIE, Bellingham, WA, 2007) Article CID Number.

ISSN 0277-786X

ISBN 9780819468321

Published by

SPIE

P.O. Box 10, Bellingham, Washington 98227-0010 USA

Telephone +1 3606763290 (Pacific Time) · Fax +1 3606471445

SPIE.org

Copyright (c) 2007, Society of Photo-Optical Instrumentation Engineers

Copying of material in this book for internal or personal use, or for the internal or personal use of specific clients, beyond the fair use provisions granted by the U.S. Copyright Law is authorized by SPIE subject to payment of copying fees. The Transactional Reporting Service base fee for this volume is $\$ 18.00$ per article (or portion thereof), which should be paid directly to the Copyright Clearance Center (CCC), 222 Rosewood Drive, Danvers, MA 01923. Payment may also be made electronically through CCC Online at copyright.com. Other copying for republication, resale, advertising or promotion, or any form of systematic or multiple reproduction of any material in this book is prohibited except with permission in writing from the publisher. The CCC fee code is $0277-786 \mathrm{X} / 07 / \$ 18.00$.

Printed in the United States of America.

Publication of record for individual papers is online in the SPIE Digital Library.

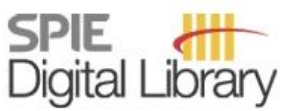

SPIEDigitalLibrary.org

Paper Numbering: Proceedings of SPIE follow an e-First publication model, with papers published first online and then in print and on CD-ROM. Papers are published as they are submitted and meet publication criteria. A unique, consistent, permanent citation identifier (CID) number is assigned to each article at the time of the first publication. Utilization of CIDs allows articles to be fully citable as soon they are published online, and connects the same identifier to all online, print, and electronic versions of the publication. SPIE uses a six-digit CID article numbering system in which:

- The first four digits correspond to the SPIE volume number.

- The last two digits indicate publication order within the volume using a Base 36 numbering system employing both numerals and letters. These two-number sets start with $00,01,02,03,04,05$, 06, 07, 08, 09, OA, OB ... 0Z, followed by 10-1Z, 20-2Z, etc.

The CID number appears on each page of the manuscript. The complete citation is used on the first page, and an abbreviated version on subsequent pages. Numbers in the index correspond to the last two digits of the six-digit CID number. 


\section{Contents}

ix Conference Committee

PREPARING FOR GEOSS I

668402 Global space-based inter-calibration system (GSICS) (Invited Paper) [6684-01]

M. D. Goldberg, NOAA/NESDIS (USA)

668403 A 20-year MSU dataset for atmospheric temperature change studies [6684-02]

C.-Z. ZOU, M. Gao, NOAA/NESDIS (USA)

668404 Validation of the onboard radiometric calibration of the GOES I-M visible channel by reflectance-based vicarious methods [6684-03]

N. P. Leisso, K. J. Thome, J. S. Czapla-Myers, College of Optical Sciences, Univ. of Arizona (USA)

668405 Developing a solar channel calibration algorithm for the Korean geostationary satellite COMS (Invited Paper) [6684-04]

B.-J. Sohn, H.-W. Chun, Seoul National Univ. (South Korea)

\section{PREPARING FOR GEOSS II}

668406 Back to the future: transition from operations to research (Invited Paper) [6684-05] P. E. Ardanuy, Raytheon Information Solutions (USA); D. A. Santek, Univ. of Wisconsin, Madison (USA); A. M. Tarro, Raytheon Information Solutions (USA); J. W. Wegiel, Raytheon Space Systems (USA)

668407 Calibration of AVHRR sensors using the reflectance-based method [6684-06]

J. S. Czapla-Myers, K. J. Thome, N. P. Leisso, College of Optical Sciences, Univ. of Arizona (USA)

668408 Improving the SNO calibration accuracy for the reflective solar bands of AVHRR and MODIS [6684-07]

C. Cao, X. WU, NOAA/NESDIS (USA); A. WU, Science Systems and Applications, Inc. (USA); X. Xiong, NASA Goddard Space Flight Ctr. (USA)

668409 The calibration of AVHRR visible dual gain using Meteosat-8 for NOAA-16 to 18 [6684-08] D. R. Doelling, Science Systems and Applications, Inc. (USA); D. P. Garber, NASA Langley Research Ctr. (USA); L. A. Avey, Science Systems and Applications, Inc. (USA); L. Nguyen, P. Minnis, NASA Langley Research Ctr. (USA)

6684 OA Global space-based inter-calibration system (GSICS): a status report (Invited Paper) [6684-09]

X. WU, M. Goldberg, NOAA/NESDIS (USA) 
6684 OE The EUMETSAT Polar System: status and first results (Invited Paper) [6684-14]

K. D. Klaes, J. Schmetz, EUMETSAT (Germany)

6684 OF Applications of IASI on MetOp-A: first results and illustration of potential use for meteorology, climate monitoring, and atmospheric chemistry (Invited Paper) [6684-15] T. Phulpin, D. Blumstein, F. Prel, Ctr. National d'Études Spatiales (France); B. Tournier, P. Prunet, Noveltis (France); P. Schlüssel, EUMETSAT (Germany)

$6684 \mathrm{OH}$ In-flight performance of the infrared atmospheric sounding interferometer (IASI) on METOPA [6684-17] D. Blumstein, CNES-CST (France); B. Tournier, Noveltis (France); F. R. Cayla, SISCLE (France); T. Phulpin, R. Fjortoft, C. Buil, G. Ponce, CNES-CST (France)

REMOTE SENSING ALGORITHM AND DATA ANALYSIS I

6684 Ol Simulation of atmospheric profile retrieval from hyperspectral infrared data under cloudy condition [6684-18]

L. Guan, Nanjing Univ. of Information Science and Technology (China); H. L. Huang, Univ. of Wisconsin, Madison (USA)

$66840 \mathrm{~J}$ A study on the accuracies of ozone data observed with ground-based and satellite-borne instruments (Invited Paper) [6684-19]

Z. Wang, J. Zhang, Nanjing Univ. of Information Science and Technology (China); H. Chen, Institute of Atmospheric Physics (China); Z. Zhang, Z. He, Nanjing Univ. of Information

Science and Technology (China)

6684 OK An improved atmospheric profile retrieval system for GOES sounder and SEVIRI data [6684-20]

X. Jin, J. Li, J. Nelson, C. Schmidt, Z. Li, Univ. of Wisconsin, Madison (USA); T. Schmit, M. Goldberg, NESDIS/NOAA (USA)

$6684 \mathrm{OL}$ The simultaneous retrieval of hyperspectral IR emissivity spectrum along with temperature and moisture profiles from AIRS [6684-21]

J. Li, J. Li, E. Weisz, Univ. of Wisconsin, Madison (USA); T. Schmit, M. Goldberg,

NOAA/NESDIS(USA); D. Zhou, NASA Langley Research Ctr. (USA)

6684 OM Improved atmospheric soundings and error estimates from analysis of AIRS/AMSU data [6684-22]

J. Susskind, NASA Goddard Space Flight Ctr. (USA)

REMOTE SENSING ALGORITHM AND DATA ANALYSIS II

668400 All Sky soundings from hyperspectral infrared radiances alone (Invited Paper) [6684-24] J. Li, E. Weisz, J. Li, X. Jin, C.-Y. Liu, Univ. of Wisconsin, Madison (USA); D. K. Zhou, Langley Research Ctr., NASA (USA); T. J. Schmit, NESDIS/NOAA (USA); A. Huang, Univ. of Wisconsin, Madison (USA); M. D. Goldberg, NESDIS/NOAA (USA) 
6684 OP Evaluation of data thinning for climate applications using the first four years of AIRS hyperspectral data [6684-25]

H. H. Aumann, E. Fishbein, J. Gohlke, Jet Propulsion Lab. (USA)

$66840 Q \quad$ Improved MODIS aerosol retrieval over urban scenes [6684-26]

M. M. Oo, E. Hernandez, M. Jerg, B. M. Gross, F. Moshary, S. A. Ahmed, City College of New York (USA)

\section{REMOTE SENSING WEATHER: CLIMATE AND ENVIRONMENTAL APPLICATIONS I}

$6684 \mathrm{OR}$ The relationship between the interdecadal variability of East Asian summer monsoon's movement and the spatial distribution pattern of the summer rainfall in East China [6684-27] $X$. Lü, Institute of Oceanology (China) and Graduate School of the Chinese Academy of Sciences (China); X. Zhang, Beijing Climate Ctr. (China); J. Chen, Institute of Oceanology (China)

6684 OT Moisture structure of ISO in Western North Pacific revealed by AIRS [6684-29] L. Tao, Nanjing Univ. of Information Sciences and Technology (China); X. Fu, B. Wang, Univ. of Hawaii at Manoa (USA)

6684 OU Characteristics of Tibetan Plateau topographic trough and Bay of Bengal trough and their relationship with the South China Sea summer monsoon onset [6684-30] J. Wei, J. He, S. Zhong, NUIST (China)

6684 OV Possible mechanism of the south-born-south-persisting West Pacific subtropical high double ridges process [6684-31]

L. Qi, Nanjing Univ. of Information Science and Technology (China) and National Climate Ctr. (China); Z. Zhang, National Climate Ctr. (China); J. Hai, Z. Guan, Nanjing Univ. of Information Science and Technology (China)

\section{REMOTE SENSING WEATHER: CLIMATE AND ENVIRONMENTAL APPLICATIONS II}

6684 OW Zonal thermal difference between East Asia and West Pacific and its relationship with East Asian subtropical southerly onset [6684-32]

J. He, Nanjing Univ. of Information Science and Technology (China); L. Qi, Nanjing Univ. of Information Science and Technology (China) and National Climate Ctr. (China); Z. Zhang, National Climate Ctr. (China)

6684 0X Techniques for comprehensive risk assessment of climatic drought in winter wheat production in Northern China [6684-33]

R. Liu, Z. Zhu, W. Fang, Y. Wang, Z. Ma, P. Xu, Henan Institute of Meteorological Sciences (China)

6684 OY Mechanisms of droughts and their patterns during winter wheat growing season in Henan Province of China [6684-34]

S. Shen, L. Cheng, Nanjing Univ. of Information Science and Technology (China); R. Liu, W. Kang, S. Li, Henan Institute of Meteorology (China) 
$66840 Z$ Climatic characteristics of QTP atmospheric heat source in 1961-2001 [6684-35]

S. Zhong, J. He, Z. Guan, X. Liu, Nanjing Univ. of Information Science and Technology

(China); S. Yuan, Agricultural Univ. of Hebei (China)

668410 Observations of deep convective clouds as stable reflected light standard for climate research: AIRS evaluation [6684-36]

H. H. Aumann, T. Pagano, M. Hofstadter, Jet Propulsion Lab. (USA)

\section{REMOTE SENSING DATA ARCHIVING, MANAGEMENT, AND DISTRIBUTION}

668411 The telesupervised adaptive ocean sensor fleet [6684-37]

A. Elfes, Jet Propulsion Lab. (USA); G. W. Podnar, J. M. Dolan, S. Stancliff, E. Lin, Carnegie Mellon Univ. (USA); J. C. Hosler, T. J. Ames, NASA Goddard Space Flight Facility (USA);

J. Moisan, T. A. Moisan, NASA Wallops Flight Facility (USA); J. Higinbotham, Emergent Space Technologies (USA); E. A. Kulczycki, Jet Propulsion Lab. (USA)

668412 Sensor networks and netcentric perspectives of civil government (Invited Paper) [6684-38] D. R. Jones, National Oceanic and Atmospheric Administration, National Weather Service (USA); T. G. Howard, National Oceanic and Atmospheric Administration, National Weather Service (USA) and American Institute of Aeronautics and Astronautics (USA)

668413 Simulation for the design of next-generation global Earth observing systems (Invited Paper) [6684-39]

M. S. Seablom, S. J. Talabac, NASA Goddard Space Flight Ctr. (USA); G. J. Higgins,

B. T. Womack, Northrop Grumman IT TASC (USA)

668414 Sensor webs with a service-oriented architecture for on-demand science products (Invited Paper) [6684-40]

D. Mandl, NASA Goddard Space Flight Ctr. (USA); R. Sohlberg, C. Justice, Univ. of Maryland, College Park (USA); S. Ungar, T. Ames, NASA Goddard Space Flight Ctr. (USA); S. Frye, Noblis (USA); S. Chien, D. Tran, Jet Propulsion Lab. (USA); P. Cappelaere, Vightel (USA); L. Derezinski, Innovative Solutions (USA); G. Paules, Kelly, Anderson \& Associates (USA); D. SUllivan, NASA/ARC (USA); L. Di, George Mason Univ. (USA); S. Kolitz, Draper Lab. (USA)

668415 A prototype of land information sensor web (LISW) [6684-41] H. Su, Ctr. for Research on Environment and Water (USA); P. R. Houser, Ctr. for Research on Environment and Water (USA) and George Mason Univ. (USA); Y. Tian, Univ. of Maryland, Baltimore County (USA) and NASA Goddard Space Flight Ctr. (USA); J. V. Geiger, NASA Goddard Space Flight Ctr. (USA); S. V. Kuma, Univ. of Maryland, Baltimore County (USA) and NASA Goddard Space Flight Ctr. (USA); D. R. Belvedere, Ctr. for Research on Environment and Water (USA)

\section{POSTER SESSION}

668417 Radiance comparison of IASI and AVHRR on MetOp-A [6684-43]

L. Wang, QSS Group, Inc. (USA); C. Cao, NOAA/NESDIS/STAR (USA) 
668419 Analysis of interannual features of tropical cyclones originating from the monsoon trough in the western North Pacific [6684-46]

J. Gao, Provincial Climate Ctr. of Fujian (China); X. Zhang, National Climate Ctr. of China (China); Z. Jiang, Nanjing Univ. of Information Science and Technology (China); X. LŪ, Institute of Oceanology (China)

$66841 \mathrm{~A}$ Study on impacts of an exceptionally intense sandstorm upon Gansu region in summer [6684-47]

X. Wang, Lanzhou Institute of Arid Meteorology (China) and Lanzhou Central Meteorological Observatory (China); Y. Huang, Z. Liu, Lanzhou Institute of Arid Meteorology (China); F. Wei, Dingxi City Meteorological Bureau (China); T. Zhang, Lanzhou Institute of Arid Meteorology (China)

6684 1B Characteristic of surface water resources and response to climate change in northwest of China [6684-49]

J. Feng, Institute of Arid Meteorology (China); L. Sun, Lanzhou Regional Climate Ctr. (China); H. Guo, Institute of Arid Meteorology (China)

6684 1C The trends of water vapor and methane in the stratosphere [6684-51]

C. Shi, Nanjing Univ. of Information Science and Technology (China); Y. Chen, Univ. of Science and Technology of China (China); S. Zhong, Nanjing Univ. of Information Science and Technology (China)

6684 1D HYDRA [6684-52]

T. Rink, P. Menzel, T. Achtor, T. Whitaker, Univ. of Wisconsin, Madison (USA)

6684 1E Improved processing of multi-filter rotating shadowband radiometer network for distributed monitoring [6684-53]

M. Bustamante, B. Gross, F. Moshary, S. Ahmed, The City College of the Univ. of New York (USA)

6684 IF A new concept: double ridges process of West Pacific subtropical high [6684-54] J. He, L. Qi, Nanjing Univ. of Information Science and Technology (China); Z. Zhang, National Climate Ctr. (China)

$6684 \mathrm{1H} \quad$ Intercalibrating geostationary imagers via polar orbiting high spectral resolution data [6684-56]

M. M. Gunshor, Cooperative Institute for Meteorological Satellite Studies (USA); T. J. Schmit, NOAA/NESDIS/STAR/ASPB (USA); W. P. Menzel, D. Tobin, Cooperative Institute for Meteorological Satellite Studies (USA)

$668411 \quad$ Lidar measurements for the short-term forecast of meteorological stability [6684-57] Y. Polkanov, B.I. Stepanov Institute of Physics (Belarus)

Author Index 
Downloaded From: https://www.spiedigitallibrary.org/conference-proceedings-of-spie on 26 Apr 2023

Terms of Use: https://www.spiedigitallibrary.org/terms-of-use 


\title{
Conference Committee
}

\author{
Conference Chairs \\ Mitchell D. Goldberg, Center for Satellite Applications and Research, \\ National Environmental Satellite Data and Information Service, \\ NOAA (USA) \\ Hal J. Bloom, NOAA, NPOESS Integrated Program Office (USA) \\ Allen H. Huang, University of Wisconsin, Madison (USA) \\ Philip E. Ardanuy, Raytheon Information Solutions (USA)
}

Program Committee

John J. Bates, NOAA (USA)

James J. Butler, NASA Goddard Space Flight Center (USA)

Changyong Cao, National Environmental Satellite Data and Information Service, NOAA (USA)

Gerald J. Dittberner, NOAA (USA)

Wei Gao, Colorado State University (USA)

John F. Le Marshall, Bureau of Meteorology (USA)

Stephen A. Mango, NOAA, NPOESS Integrated Program Office (USA)

Johannes Schmetz, EUMETSAT (Germany)

William L. Smith, Jr., NASA Langley Research Center (USA)

Session Chairs

1 Preparing for GEOSS I

Thomas H. Achtor, University of Wisconsin, Madison (USA)

2 Preparing for GEOSS II

Xiangqian Wu, Center for Satellite Applications and Research, National Environmental Satellite Data and Information Service, NOAA (USA)

3 Remote Sensing Program, System, and Sensor I

Thierry Phulpin, Centre National d'Études Spatiales (France)

$4 \quad$ Remote Sensing Program, System, and Sensor II

Dieter Klaes, EUMETSAT (Germany)

5 Remote Sensing Algorithm and Data Analysis I

Jun Li, University of Wisconsin, Madison (USA) 
6 Remote Sensing Algorithm and Data Analysis II

Hal J. Bloom, NOAA, NPOESS Integrated Program Office (USA)

$7 \quad$ Remote Sensing Weather: Climate and Environmental Applications I

Zhenhui Wang, Nanjing University of Information Science and Technology (China)

$8 \quad$ Remote Sensing Weather: Climate and Environmental Applications II

Byung-Ju Sohn, Seoul National University of Technology (South Korea)

9 Remote Sensing Data Archiving, Management, and Distribution

Philip E. Ardanuy, Raytheon Information Solutions (USA)

Valliappa Lakshmanan, University of Oklahoma (USA) 